
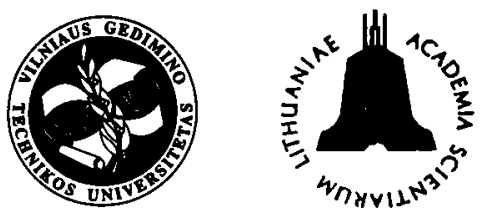

JOURNAL OF CIVIL ENGINEERING AND MANAGEMENT

http:/www.vtu.lt/english/editions

2003. Vol IX, No 2, 110-114

\title{
THE DURABILITY OF PAINTS ON SAND-LIME BRICK WALLS CONSIDERING WATER SORPTION AND VAPOUR PERMEABILITY IN A TWO-LAYER SYSTEM
}

\author{
Rūta Miniotaité1, Vytautas Stankevičius ${ }^{2}$ \\ ${ }^{1}$ Faculty of Civil Engineering and Architecture, Kaunas University of Technology, \\ Studentu g. 48, LT-3031 Kaunas, Lithuania.E-mail: rutaminiot@centras.lt \\ ${ }^{2}$ Laboratory of Building Thermal Physics, Institute of Architecture and Construction, \\ Tunelio g.60,LT-3035 Kaunas, Lithuania.E-mail: silfiz@asi.lt
}

Received 04 Sept 2002; accepted 16 Jan 2003

\begin{abstract}
It is assumed that the proposed coatings are suitable for finishing selected surfaces. However, our research indicated that the provided specific physical-mechanical properties of the coatings may change in a new combination of "coating - substrate". It was found while analysing the results of grouped paints investigations that specific nature of vapour permeability and absorption, the effect of opposition thereof, the expansion of destruction and expression of its symptoms were characteristic of each group. Physical-mechanical properties of constructions substrate and finishing layer can supplement one another or, quite contrary, stimulate destruction. Analytical review of the influence made by two parameters (vapour resistance and rain penetration) upon durability of paints of various structural origins indicated that usually rain-penetration influence was higher. However, while evaluating humidity of complete finished layer (paint + substrate) as a process: "rain penetration - moisture migration from the inside (drying) - vapour isolation of the coating as a barrier to drying process", in case of film-forming paints the influence of vapour resistance is high too.
\end{abstract}

Keywords: paints, physical-mechanical properties, interaction of materials, service life.

\section{Introduction}

Vapour permeability and water sorption processes of individual materials are sufficiently well analysed and known [1-14]. However, the parameters were obtained irrespective of paint-substrate interaction. On the other hand, the importance of adverse effect of the above processes upon adhesion of the paint and destruction was not evaluated.

A lot of various finishing materials are provided on the market; however, physical-mechanical properties are strictly peculiar. The interaction of combinations of such materials as paint, mastic, dry mixtures with the materials of finishing surfaces is rather complicated [8-9]. A task is set to investigate the reaction of complex derivative of finishing layer forming materials with surface layer of walls as well as of the above materials to external effects and their intensivity.

Since several hundreds of combinations can be formed when using paints for different surfaces, sandlime brick was chosen for the investigation. The choice was predetermined by the advantages of sand-lime brick surface and comparatively homogeneous capillary structure [15-20], so that less scattered results might be obtained.

\section{Method and results}

2.1. Investigation of water vapour permeability and surface water sorption in a two-layer (painted sandlime brick) system

Water vapour permeability coefficient was determined in $20^{\circ} \mathrm{C}$ environment according to requirements of the standard [14].

Vapour permeability coefficients were determined by preparation of 6 specimens of $100 \mathrm{~mm}$ diameter and about $25 \mathrm{~mm}$ thickness: 3 specimens of the materials without paint and three specimens with surfaces already painted. The painted specimens were fixed to a cup, paint facing down (cup method) [21-22]. The same specimens were used for detecting the surface water sorption. Measurement results are given in Tables 1, 2 .

According to various values of paint vapour permeability, three level groups of paints can be distinguished. The first level group paints are of low vapour permeability coefficient $\delta_{p}<0,032 \mathrm{mg} /(\mathrm{m} \cdot \mathrm{h} \cdot \mathrm{Pa})$, there are no silicate paints. Silicone paints vapour permeability depends solely upon concentration. The second level group paints are with permeability $\delta_{p}=(0,032-0,048)$ $\mathrm{mg} /(\mathrm{m} \cdot \mathrm{h} \cdot \mathrm{Pa})$. Paints of all groups according to paint nature belong to this (permeability) level group. The third 
Table 1. Physical factors and resistance to complex effects of silicone paints on sand-lime brick walls

\begin{tabular}{|c|c|c|c|c|c|c|}
\hline \multirow{3}{*}{\multicolumn{2}{|c|}{$\begin{array}{c}\text { Subgroup and } \\
\text { paints mark }\end{array}$}} & \multicolumn{4}{|c|}{ Physical factors } & \multirow{3}{*}{$\begin{array}{c}\text { Resistance to } \\
\text { complex effects } C \text {, } \\
\text { cycles }\end{array}$} \\
\hline & & \multirow{2}{*}{$\begin{array}{c}\text { Vapour } \\
\text { permeability } \\
\text { coefficient } \delta_{p}, \\
\mathrm{mg} /(\mathrm{m} \cdot \mathrm{h} \cdot \mathrm{Pa})\end{array}$} & \multicolumn{2}{|c|}{ Vapour resistance, $\mathrm{m}^{2} \cdot \mathrm{h} \cdot \mathrm{Pa} / \mathrm{mg}$} & \multirow{2}{*}{$\begin{array}{l}\text { Water sorption } \\
\text { coefficient } w \\
\mathrm{~kg} /\left(\mathrm{m}^{2} \cdot \mathrm{h}^{0,5}\right)\end{array}$} & \\
\hline & & & Brick layer $Z_{p}$ & Paints $Z$ & & \\
\hline & 0 & 0,054 & 0,462 & 0 & 0,942 & 180 \\
\hline \multirow[t]{3}{*}{$a$} & 18 & 0,046 & 0,545 & 0,083 & 0,288 & 116 \\
\hline & EAS & 0,028 & 0,897 & 0,435 & 0,029 & 116 \\
\hline & HSX & 0,026 & 0,946 & 0,484 & 0,070 & 71 \\
\hline \multirow[t]{4}{*}{$b$} & 16 & 0,037 & 0,678 & 0,216 & 0,081 & 116 \\
\hline & 21 & 0,033 & 0,757 & 0,295 & 0,062 & 119 \\
\hline & SV & 0,027 & 0,942 & 0,480 & 0,051 & 179 \\
\hline & SO & 0,026 & 0,966 & 0,504 & 0,101 & 179 \\
\hline
\end{tabular}

Note. 0 - non-painted brick.

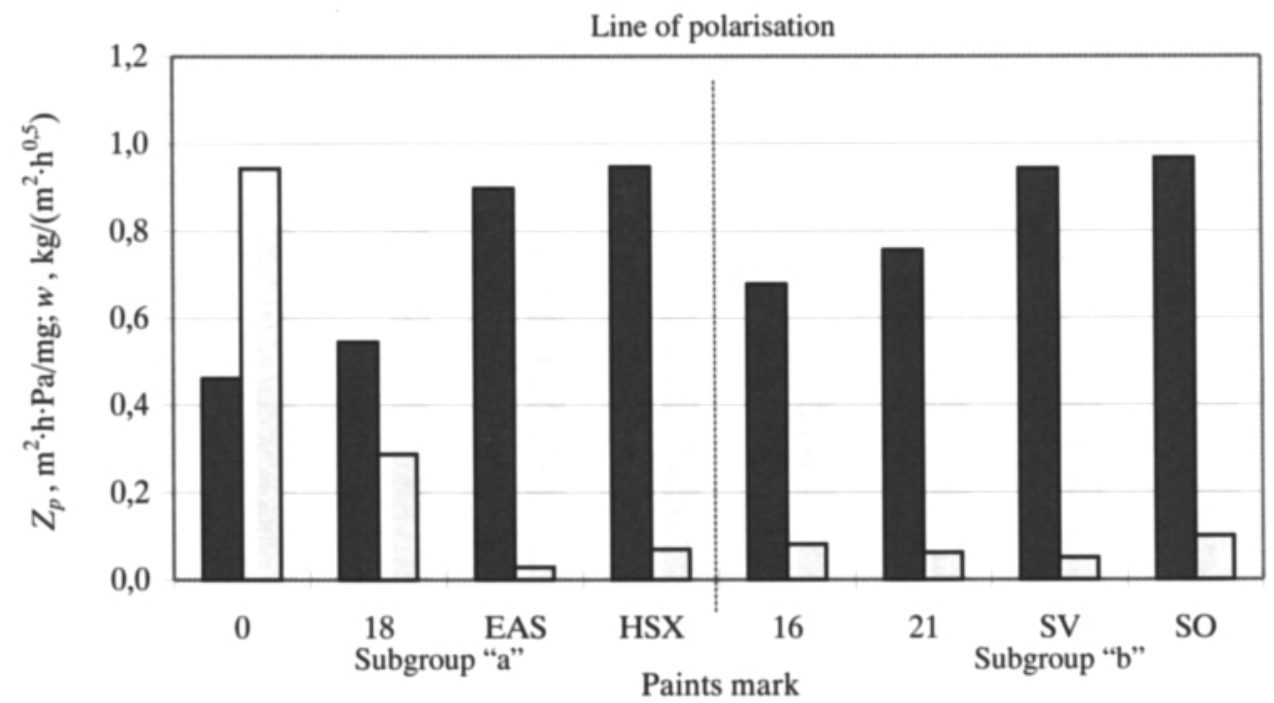

Vapour resistance $Z_{p} \quad \square$ Water sorption coefficient $w$

Fig 1. Comparison of variation in vapour resistance and water sorption coefficients of silicone applied to sand-lime bricks

level group coatings are of high permeability $\delta_{p}=(0,048-0,054) \mathrm{mg} /(\mathrm{m} \cdot \mathrm{h} \cdot \mathrm{Pa})$. Nearly all groups of silicate coatings belong to the third vapour permeability group. There are no paints of silicone and only one of polyacrylates.

Analyses of all the compositions of the paint groups indicate that vapour permeability depends on the paint used, on polarity of film-makers and on bonding agents applied. Silicate paints are particularly sensitive to the above ingredients.

Water vapour resistance $Z_{p},\left[\mathrm{~m}^{2} \cdot \mathrm{h} \cdot \mathrm{Pa} / \mathrm{mg}\right]$ is in reverse proportion to vapour permeability $\delta_{p}$ :

$$
Z_{p}=\frac{d_{x}}{\delta_{p}},
$$

where $d_{x}-$ a thickness of samples of bricks, $\mathrm{m}$.

Results of investigation and comparison of vapour resistances and water sorption coefficients of coated sand- lime bricks $\left(d_{x}=0,025 \mathrm{~m}\right)$ are given in Table 1, Fig 1; Table 2, Fig 2 .

Silicone paints are classified in two subgroups: a) paints containing pigments: 18 , EAS, HSX; b) paints without pigments: $16,21, \mathrm{SV}$, SO. Silicone paints in the subgroups are located in increasing order of vapour resistance, supposing that vapour resistance effect on durability will be higher than that of water sorption coefficient.

Fig 1 illustrates that all silicone compositions (except for mark 18$)$ show a high vapour resistance $\left(Z_{p}=\right.$ $\left.0,68 \div 1,0 \mathrm{~m}^{2} \cdot \mathrm{h} \cdot \mathrm{Pa} / \mathrm{mg}\right)$ and low water sorption $(w \leq 0,1 \mathrm{~kg} /$ $\left(\mathrm{m}^{2} \cdot \mathrm{h}^{0,5}\right)$.

As can be seen (from Fig 2), with an increase of vapour resistance less than twice, water sorption coefficient decreases more than 30 times. Aqueous disperse paints are polaried according to water sorption coefficient in two subgroups: a) paints $1,3,2,8(w=$ $\left.0,81 \div 0,6 \mathrm{~kg} /\left(\mathrm{m}^{2} \cdot \mathrm{h}^{0,5}\right) ; \mathrm{b}\right)$ paints $20, \mathrm{AVA}, \mathrm{N}, \mathrm{EAF}, \mathrm{AE}$ 
Table 2. Physical factors and resistance to complex effects of aqueous polymeric disperse paints on sand-lime brick walls

\begin{tabular}{|c|c|c|c|c|c|c|}
\hline \multirow{3}{*}{\multicolumn{2}{|c|}{$\begin{array}{l}\text { Subgroup and } \\
\text { paints mark }\end{array}$}} & \multicolumn{4}{|c|}{ Physical factors } & \multirow{3}{*}{$\begin{array}{c}\text { Resistance to } \\
\text { complex effects } C \text {, } \\
\text { cycles }\end{array}$} \\
\hline & & \multirow{2}{*}{$\begin{array}{c}\text { Vapour } \\
\text { permeability } \\
\text { coefficient } \delta_{p} \text {, } \\
\mathrm{mg} /(\mathrm{m} \cdot \mathrm{h} \cdot \mathrm{Pa})\end{array}$} & \multicolumn{2}{|c|}{ Vapour resistance, $\mathrm{m}^{2} \cdot h \cdot \mathrm{Pa} / \mathrm{mg}$} & \multirow{2}{*}{$\begin{array}{l}\text { Water sorption } \\
\text { coefficient } w \text {, } \\
\mathrm{kg} /\left(\mathrm{m}^{2} \cdot \mathrm{h}^{0,5}\right)\end{array}$} & \\
\hline & & & Brick layer $Z_{p}$ & Paints $Z$ & & \\
\hline & 0 & 0,054 & 0,462 & 0 & 0,942 & 180 \\
\hline \multirow[t]{4}{*}{$a$} & 1 & 0,052 & 0,486 & 0,024 & 0,811 & 54 \\
\hline & 3 & 0,052 & 0,485 & 0,023 & 0,654 & 110 \\
\hline & 2 & 0,053 & 0,476 & 0,014 & 0,650 & 121 \\
\hline & 8 & 0,041 & 0,618 & 0,156 & 0,602 & 148 \\
\hline \multirow[t]{5}{*}{$b$} & 20 & 0,033 & 0,758 & 0,296 & 0,101 & 179 \\
\hline & AVA & 0,032 & 0,776 & 0,314 & 0,040 & 102 \\
\hline & $\mathrm{N}$ & 0,032 & 0,776 & 0,314 & 0,038 & 179 \\
\hline & $\mathrm{EAF}$ & 0,030 & 0,840 & 0,380 & 0,032 & 179 \\
\hline & $\mathrm{EA}$ & 0,038 & 0,658 & 0,195 & 0,024 & 82 \\
\hline
\end{tabular}

Note. 0 - non-painted brick

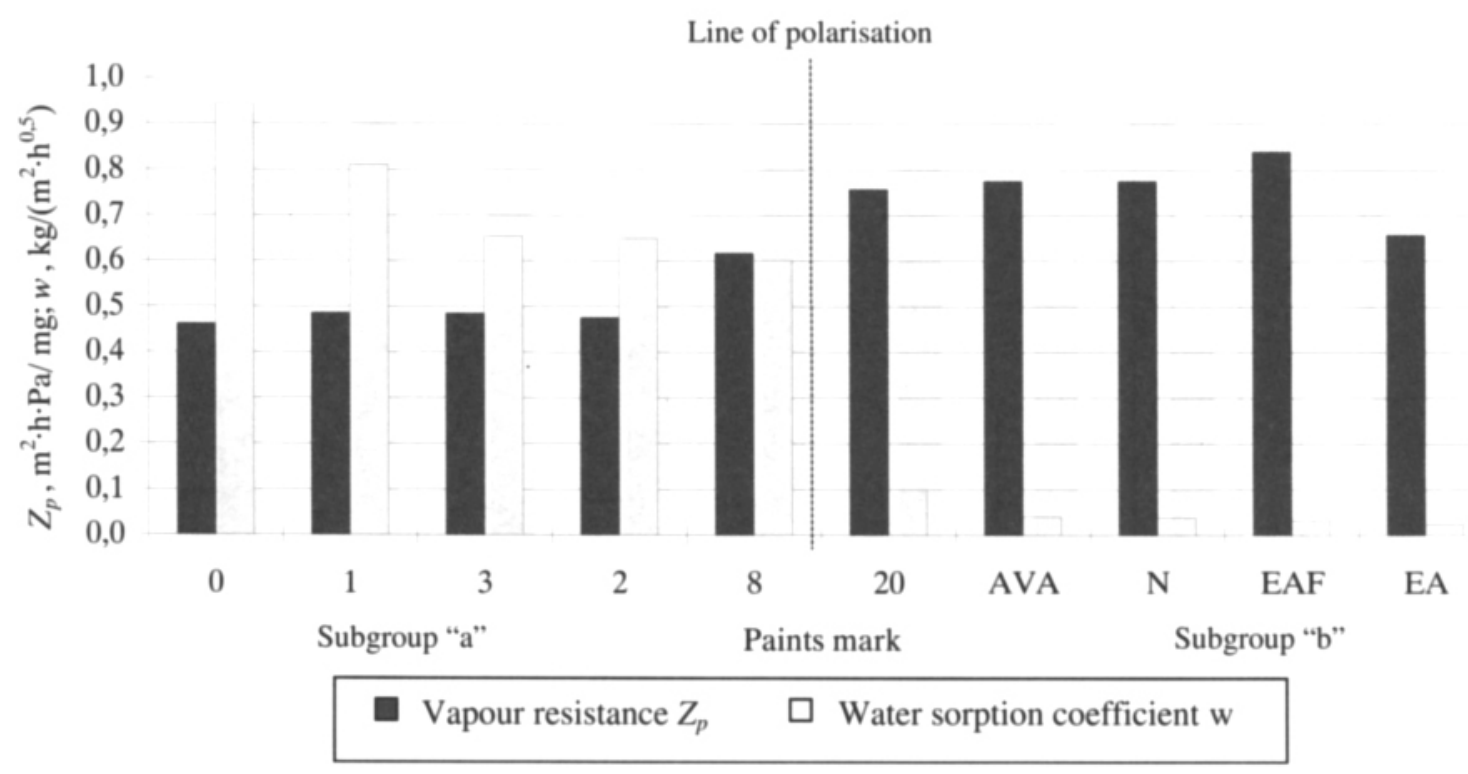

Fig 2. Comparison of variation in water sorption coefficients and in vapour resistances of aqueous polymeric disperse paints applied to sand-lime bricks

$\left(w \leq 0,1 \mathrm{~kg} /\left(\mathrm{m}^{2} \cdot \mathrm{h}^{0,5}\right)\right.$. Water sorption coefficients of neighbouring paints ( 8 and 20 ) in separate subgroups vary 6 times.

One can ask if approximate durability of paints can be predicted according to individually taken quality parameters of paints. Is the preconceived statement: low vapour resistance - low rain penetration - "good"; high vapour resistance - high rain penetration - "bad" reliable? With that end in view, special preliminary investigations into durability were carried out.

\subsection{Investigations in the durability of painted sand- lime brick surfaces considering water sorption coeffi- cient and vapour permeability}

Resistance (in modelled cycles) to complex effects was compared with resistance of non-painted surface of brick. It was determined that resistance of non-painted surface of silicate brick was about 180 cycles. After 170 180 cycles, binding hydrosilicate crystal structure of sandlime brick surface layer $(0,05 \div 0,2) \mathrm{mm}$ disintegrates. Afterwards, fine sand particles (filling), hydro-silicates disintegration products and inclusions of paint, dirt and other adhered aerosols easily fall off or are washed away.

Resistance to complex effects test was carried out in a climate chamber. Graphic views of resistance to complex effects are given in Figs 3, 4. Values of physical factors and resistance to complex effects are written in Tables 1, 2 .

Durable paints are considered able to withstand more than 150 cycles, acceptable durability coatings - those withstanding $(110 \div 150)$ cycles and indurable coatings, the durability of which is less than 110 cycles.

Paint HSX (subgroup a) large molecules of silicone resin have poor penetration into small pores of sand-lime brick. Silicone resin which does not penetrate brick, gives 


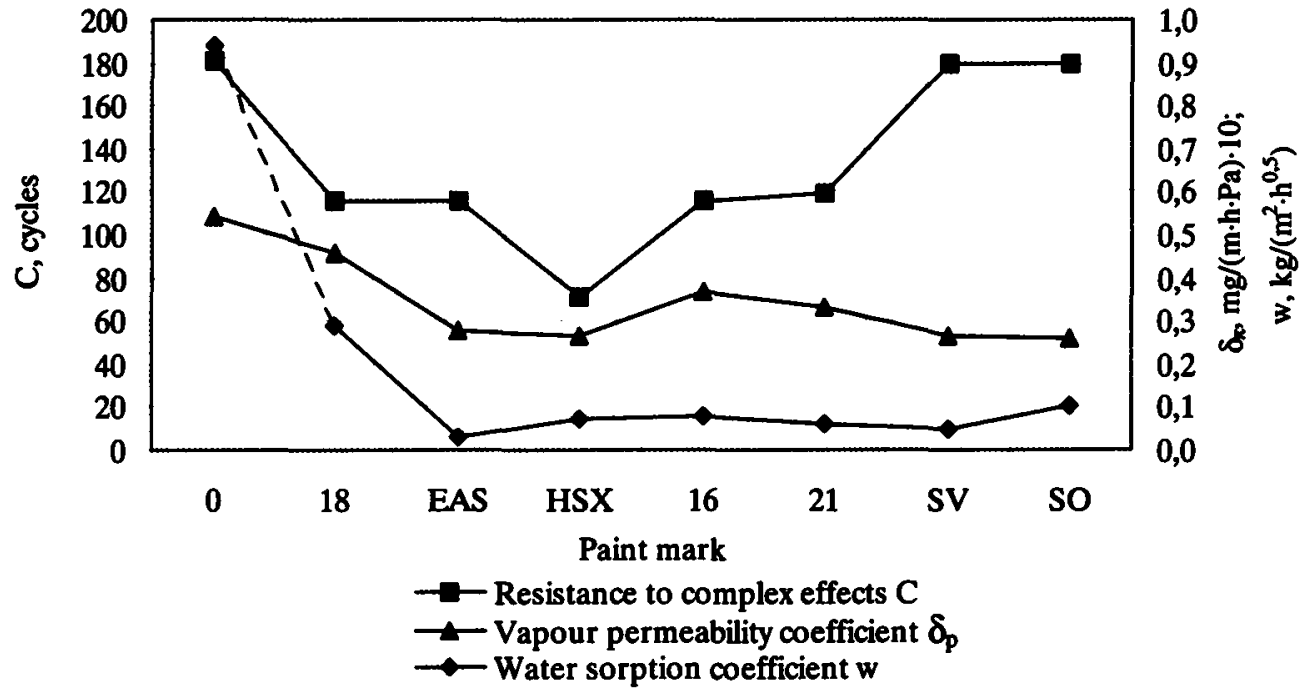

Fig 3. Resistance to complex effects of silicone paints on sand-lime brick walls considering water sorption coefficient and vapour permeability

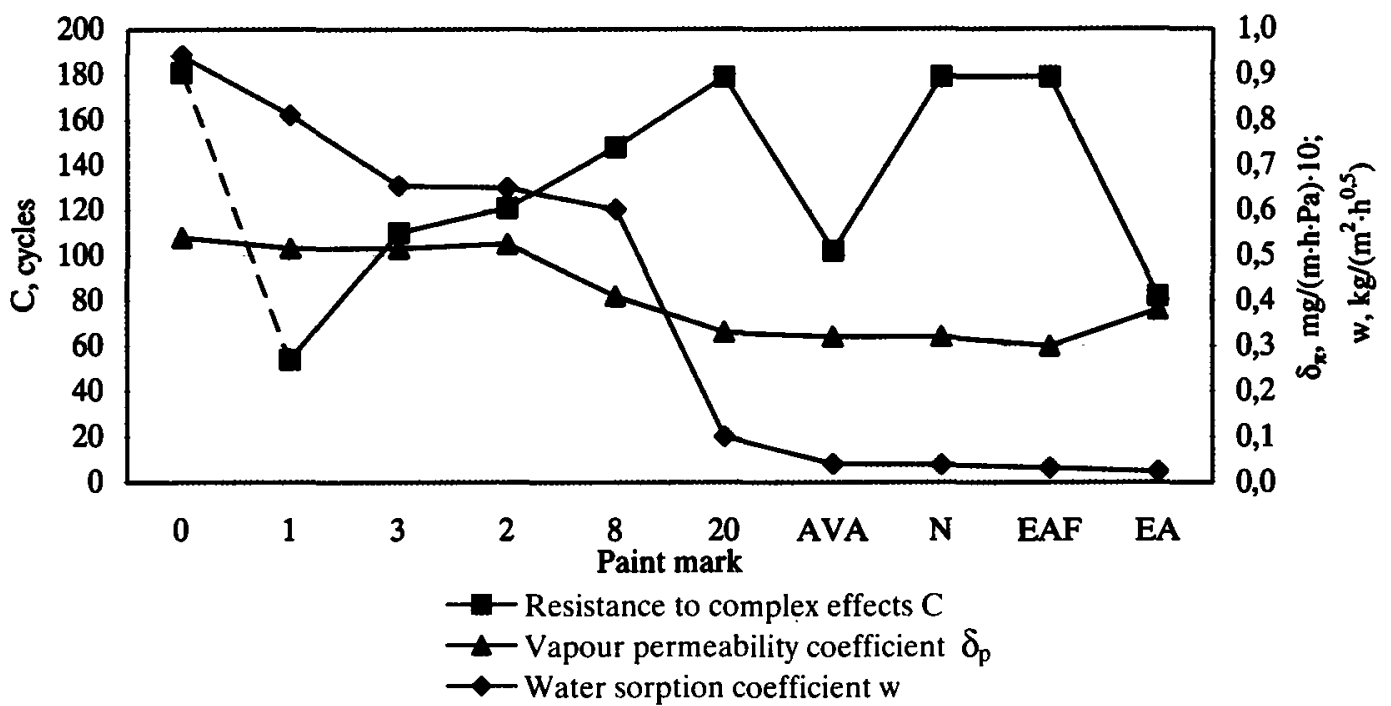

Fig 4. Resistance to climate effects of aqueous polymeric disperse paints on sand-lime brick walls considering water sorption coefficient and vapour permeability

yellow spots after 50 cycles, large blebs appear later. HSX paints cannot be used for sand-lime bricks.

Silicate paint containing no pigment " $b$ " do not peel off or crack. With time, hydrophobic properties of such paints decrease.

However, they protect the surface of sand-lime bricks sufficiently well and for a long time.

Fig 4 shows that in case of aqueous polymeric disperse paints it is difficult to say anything positive about paint durability considering vapour resistance (or permeability). The durability of such paints as well as that of the subgroups is polarised (not so distinctly due to vapour permeability decrease) in respect of water sorption coefficient. All three durable paints fall in subgroup " $b$ " where water sorption coefficients are very low.

\section{Conclusions}

1. Single-valued comparative results of paint durability and reduction of their scattering are obtained by classification of the paints according to the origin of film bonding agent and the filling: 1) paints formed out of aqueous polymeric dispersions, 2) silicate paints, 3) paints formed out of polyacrylates and silicones solutions in organic solvents or silicone dispersions.

2. Resistance of paints made out of polyacrylates and silicone solutions in organic solvents or silicone dispersions to climate effects depends upon limit values of vapour resistance determined by investigations. There are no lamination and no cracks in case of non-pigment silicone paints. Hydrophobic properties of such paints de- 
crease with time, however sand-lime brick surface is protected quite well and for a sufficiently long time.

3. Durability of paints formed out of aqueous polymeric dispersions as well as the subgroups of paints is polaried (not so distinctly due to some decrease in water vapour permeability) in the direction of fast decrease of water sorption coefficient.

\section{References}

1. Store, M. Water vapour permeability and sorption curves of painted substrates materials. In: Proc. of symposium of building physics in the Nordic countries, Finland, 1996, p. $691-698$.

2. Hansen, K. K. Equipment for and results of water vapour transmission tests using cup methods. In: Proc. of ICHMT symp. heat and mass transfer in building materials and structures, Dubrovnik, Yugoslavia, 1989, p. 127-132.

3. Hansen, K. K.; Hansen, E. J. Unfired clay bricks - moisture properties and compressive strength. In: Proc. of $6^{\text {th }}$ symposium on building physics in the Nordic countries, Trondheim, Norway, 1990, p. 453-460.

4. Miniotaitè, R.; Stankevičus, V. Sorption-desorption of Building Materials. In: Proc. of healthy buildings' 1994 conference, Budapest, Hungary, 1994, p. 141-145.

5. Miniotaitè, $R$. The durability of finishing layer external surface of building walls (Pastatų sienı dažytụ paviršiu ilgaamžiškumas). Monograph. Kaunas: Technologija, 2001. 175 p. (in Lithuanian)

6. Carmeliet, J. and Roels, S. Determination of the isothermal moisture transport properties of porous building materials. J. of Thermal Envelope \& Building Science, Vol 24, 2001, p. 183-210.

7. Bomberg, M.; Haghighat, F.; Grunewald, J.; Plagge, R. Capillary transition point as a material characteristic for HAM models. In: Proc. of $4^{\text {th }}$ int. conf. on IAQ, ventilation and energy conservation in buildings, Vol 1, 2001, p. $755-762$.

8. Freitas, V. P.; Abrantes, V.; Crausse, P. Moisture migration in building walls - analysis of the interface phenomena. Building and Environment, Vol 31, No 2, 1996, p. 99 108 .

9. Cerny, R.; Drchalova, J.; Hoskova, S.; Toman, J. Inverse problems of moisture transport in porous materials. In: Proc. of second ECCOMAS conf. on numerical methods in engineering, 1996, p. 664-670.

10. Hedenblad, G. Moisture permeability of some porous materials. In: Proc. of $3^{\text {rd }}$ symposium on building physics in the Nordic countries, Copenhagen, Vol 2, 1993, (Saxhof, B., editor), p. 697-702.
11. EN ISO 12571:2000. Building materials. Determination of hygroscopic sorption properties.

12. prEN ISO 15148. Building materials. Determination of water absorption coefficient by partial immersion, CEN/ TC 89 WG10 N 189 30-09-1997.

13. Hansen, K. K.; Baroghel, V. B.; Quenard, D. and Künzel, $H$. Water vapour absorption isotherms for porous building materials. In: Proc. of international symposium on moisture problems in building walls. Portugal, 1995, (Abrantes V., editor), p. 248-257.

14. EN ISO 12572:2001. Building materials. Hydrothermal performance of building materials and products. Determination of water vapour transmission properties.

15. Hale, D. K. The physical properties of composite materials (review). Journ. of Material Science, Vol 11, 1976, p. 2105-2141.

16. Lentinen, T. Capillary moisture transfer in combined porous building materials. In: Proc. of symposium on building physics in the Nordic countries, Finland, 1996, p. 483490.

17. Carmeliet, J. and Roels, S. Moisture transfer and durability of open porous media. In: Proc. of 4 th symposium on building physics in the Nordic countries, Finland, $\mathrm{Vol} 2$, 1996, p. 587-594.

18. Miniotaite, R. Compatibility of finishing layer and external surface of buildings walls from the standpoint of durability (Pastaty sienų išorinio apdailos sluoksnio ir pagrindo suderinamumas ilgaamžiškumo požiūriu). Doctoral dissertation, Kaunas, Lithuania, 1999. 180 p. (in Lithuanian).

19. Miniotaite, R. Determination method for weather durability of finish layers in external walls of buildings (Pastaty išorinių sienu apdailos sluoksnių atsparumo klimatui nustatymo metodika). In: Proc. of conference on the subject of construction and architecture, Kaunas University of Technology, Institute of Architecture and Construction. Kaunas: Technologija, 1996, p. 140-145 (in Lithuanian).

20. Aniskevich, A. Moisture sorption in aramid composite on different structural and physical levels. In: Proc. of tenth int. conf. on composite Materials (ICCM-10), Whistler, British Columbia, Canada, Aug 14-18, 1995, Vol IV: Characterization and ceramic matrix composites. Abington: Woodhead Publ. Ltd, 1995, p. 367-374.

21. Carmeliet, J. and Roels, S. Description of the moisture capacity of building materials In: Proc. of $6^{\text {th }}$ symposium on building physics in the Nordic countries, Trondheim, Norway, 2002, p. 485-492.

22. Hansen, K. K. Equipment for and results of water vapour transmission tests using cup methods. In: Proc. of ICHMT symp. heat and mass transfer in building materials and structures, Dubrovnik, Yugoslavia, 1989, p. 267-271. 